\title{
Economic Evaluation Air Pollution Removal and Oxygen Production based on I-Tree program for Atrush Forest/Kurdistan Region Of Iraq*
}

\author{
${ }^{1}$ Shams-Aldeen M. Qaro, 2 Zeki M. Akrawee \\ ${ }^{1}$ Duhok Polytechnic University, Akre Technical College, Department of Horticulture, Duhok, Iraq \\ ${ }^{2}$ Duhok University, College of Administration and Economics, Department of Economics, Duhok, Iraq
}

\begin{abstract}
The objectives of this study are to testing the impacts of Atrush forests on the environment and oxygen production based on ITree program, function and management decisions that will improve human health and environmental quality. Human communities derive many essential benefits from natural ecosystems; these benefits represent important and familiar parts of the economy. What has been less appreciated up to this day is that natural ecosystems also perform fundamental life-support services without them human civilizations would cease to thrive. Evaluation of the vegetation structure, conducted during 2017. Data from 21 fields located were analyzed using the I-Tree Eco program. The most common species of trees are Pinus brutia (Turkish pine). Quercus aegilops (Ajo mountain scrub oak ), Plantanus orientalis (Oriental plane tree), Pistacia atlantica (Mt.atlas mastic tree) as well as shrubs Crataegus azarolus (Mediterranean Medlar), Junipours occidentalis (Western juniper), Prunus amygdalus (Almendro), Rhus coriaria (sumac spp), Nerium oleander (Oleander). Results show that the Pollution removal is ( 0.106 ton/year) referred ( $\$ 280$ /year) for sum of surveyed trees and shrubs in Atrush location, and oxygen production is (2 ton/year) .That means there are a effected role of trees on ecosystem in selected area.
\end{abstract}

Keywords: Air pollution, Ecosystem Evaluation, Forest Economic, I-Tree Tools, Oxygen Production.

${ }^{*}$ Part of dissertation of the first researcher.

\section{Introduction}

Explanation of economic evaluation is the process of methodical recognition, quantification and assessment of the inputs and outputs of two activities, and the following relative test of these two activities. In economic evaluations, the costs and result of alternative interference to inspect the best use of the short resources certain question being inscribed by: a differentiation of the costs and advantages of a new intervention to some modern curative approach; a differentiation of the costs and benefits between dealings with and prohibition activities; and a

Academic Journal of Nawroz University

(AJNU) Volume 9, No 1 (2020).

Regular research paper: Published 19 Feb 2020

Corresponding author's e-mail : shamsaldeen.m@gmail.com Copyright (C2018 Shams-Aldeen M. Qaro, Zeki M. Akrawee. This is an open access article distributed under the Creative Commons Attribution License. differentiation of the costs and benefits between treatment and law execution activities. Economic evaluation of ecosystem services is a helpful implement to forte the pains to preserve and control physical ecosystems, on account of it utilizes a measured that is readily know (monetary units). Economic valuation cans growth community consciousness about the importance of physical ecosystems that share in to soundness, income and economy. In addition, economical assessment supply helpful values for resolution making and promote estimate in quality preservation.

All ecosystem functions are divided in to four larger groups that allow to value the ecosystem to human society, advantages and services that result from services of rule (natural bio-geochemical cycles and 
biosphere processes), natural environment (providing diversity and evolution) generate the essential prerequisites for services of production (creation of living biomass) and information (mental and recreational value).

The direct and indirect advantages that result from the above refer to ecosystem functions, are crucial for human health or safety and are, therefore, highly valuable.

Evaluation of ecosystem services (natural capital) allows demonstrating its significance and the importance of its potential management, as ecosystem services are a usual resource that belongs to and is used by everyone. The motivation of a sustainable use of these services are very few the economic valuation of ecosystem services can be estimated by inquiring into their contribution to the production of chosen (market) outputs.

Value is given to ecosystem services from the human scene, evaluating services that people understand as important (various types of goods, services and intangible benefits). If this value is not known, it cannot be given a suitable weight in the decision-making process, when decisions on economic development or sustainable management of ecosystem services are synthetic. Ecosystems supply a vast domain of services that are main for human-safety. Assess the double services obtained from ecosystems is essential to help decision-making processes at various scales .Human activities have considerably affected the planet's environment, changing the working of most of the ecosystems and menacing the worldwide biodiversity. In face of this ecological emergency.

\subsection{Research problem}

Hence, we find that the forests in Kurdistan region of Iraq do not make any economic benefits that can be mentioned; but rather, the regional government allocates funds from its budget to spend on the forests sector. Economic development of Iraqi Kurdistan Region is not associated with an increasing demand for ecosystem services. Forests are a particular focus of ecosystem concern; in many cases the value of nonwood forest products which are non-marketed may be increased faster than the values of wood and extremity products, the advantages that humans obtain from ecosystems .In spite of the fact that the link between these services, human comfort and the monetization of ecosystem services is a new connotation in Iraqi Kurdistan Region. One result is that certain forest areas are increasingly valued more than timber product for the environmental uses. Hence, the rich areas of forest will be for wildlife conservation, and the increasing attention of public proxy to managing forests is for aesthetic values, recreational, which has become an important product of forests in affluent nations, and is increasing in Iraqi Kurdistan Region whose income and urban population are growing rapidly. We have noticed over the last ten years a major economic development in the region, but, it was not on the scientific and true basis where all sectors that would derive economic development are neglected except oil, including forests as green gold, large role in the return of capital to the region and this role is few and now the government feels interest in other forest sectors.

For that the following hypothesis was putted" Forests, through the ecosystem, affect the reduction of damage caused by gases and pollutants harmful to the environment.

The objectives of this study : are to testing the impacts of Atrush forests on the environment and oxygen production based on I-Tree program, function and management decisions that will improve human health and environmental quality.

This research depended the application of $i$ - tree 
software as a methodology to reach to the results.

David J. et.al (2006) pointed out in their searched title (Air pollution removal by urban trees and shrubs in the United States), are concept concentrate of research has been on the part of urban vegetation in the forecast and humiliation of air pollutants in towns, several pieces can be into the tree, though most pieces in order to stopped are kept on the plant superficial. The catches piece often is unresolved to the atmosphere, clean off by rain, or let fall to the ground with leaf an]d twig fall[8] assessed in this research of (Economical Assessment of Investment platform for conservation of Urban Forestry). Urban forests are the respirator of a present urban city. There are increasing numeral of towns that have advanced a larger pact of the character and significance of the normal ecology of the urban forests. In modern contract neighborhood in the biggest cities remain to introduce at an increase file. The conservation of the urban forest chips in to better the rate of living for the people. The group now particularly gives the importance of demonstrate an equilibrium among economic development and environmental degree and communal interest, the clubby plans that are objected at save and help the live urban forest are of increasing importance.

In the study of Gretchen C. (1997) Title about the (Ecosystem Services: Advantages Supplied to Human Societies by Natural Ecosystems), they performed the assess med for ecosystem services in Madagascar, their massive value to people is performed, eventually obtained bigger value of ecosystem services in certain position, and scaling their value upon that of struggle ground uses is not a simple job. They referred to the production of commonsense in the study area, annex to the ecosystem services which advocate existence through cleansing of air and water, pacify of lack of rain and floods, correct and break down of wastes, pollination of crops and natural vegetation, preservation of biodiversity, limited settlement of climate, temperate of weather fragile and their impacts, capability of beautiful alluring and obscene brace that elate the human bravery.

Ninan, K. (2014) Estimated in their searches (Estimating Forest Ecosystem Services and injustice - Case Study of a Protected Area in India). This study conducted area in Nagarhole National Park NPK (also known as Rajiv Gandhi national park located in Karnataka state in South India has been selected). Conventionally forests have been valued only for the sensible advantages they transfer such as timber and non-timber forest produce. The intangible benefits provided by forests like watershed and soil protection, regulating climate, nutrient cycling, have been command ago, these are not business in ceremonial shops or demanding to evaluate. If these accounts could be prisoned and in decision making it could command to surpass keeping effect, particularly in toughen the economic case for excuse preservation of forests against amusing them to non-forest uses, in India which have reliable to impose the economic value of the services provided by its forests.

\section{Study Area}

This study is based on field practical surveys of ( Atrush Forests) which have distinct environmental and forest characteristics, where they have different tree densities, Various forest areas. The forests in these areas contain many forest trees, which are characterized by varying qualities form different vegetation coverings. The natural and artificial forest site is one of the formations of the mountainous region of Iraq.

Located in the northern part of the Kali Qeyamat mountain range and the eastern part of the heights of the Kani Mase, while it is bordered by the western part of the center of Sub-District Atrush and 
the southern part is bordered by the Sheikhan District (Ain Safni), which is within latitude (36:49) (36:53), south and longitude (43:17), (43:27) North, and at a height ranging from (669-1017) MSL has Found there trees of Pinus brutia (Turkish pine), Pinus pinea (Itailian stone pine), Quercus aegilops (Ajo mountain scrub oak), Quercus infectoria (oak spp), Platanus orientalis (Oriental plane tree) , Ficus carica (Common fig) as well as shrubs Crataegus azarolus (Meditettanean medlar), Junipours occidentalis (Western juniper), Salix babylonica (Babylon weeping willow), Prunus amygdalus (Almendro), Rhus corioria (Sumac spp), others are characterized by heavy soils (high clay content) .

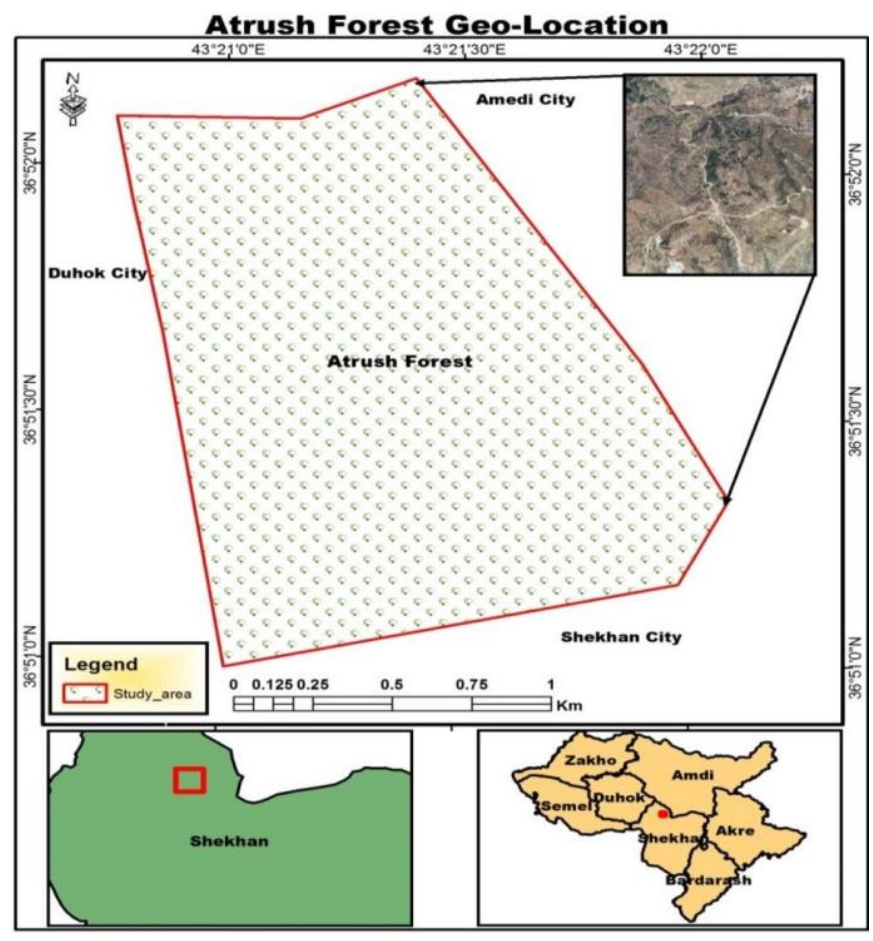

Figure 1. Atrush Forest Location.

Source: KRG,Ministry of Planning,Data and Maps General DirectorDuhok,2010

Generally, the study consists of three parts:-

First: information about the forest Evaluation of Ecosystem for forest study areas.

Second: For the assessment of the survey data are collected in forests of (Atrush) by using technique for Ecosystem, application I-Tree tools program.

Three: Result and Discussion.

\section{Materials and Methods}

The study is conducted in Duhok province/ Kurdistan region of Iraq located in area (Atrush) characterized by a changing climate over the year, soil, as well as biodiversity; forests are spread widely and diverse.

Equipment used in the study:-

The equipment used was listed below in the field surveys of study site in the forests of (Atrush):-

- Haga Altimeter:

- Caliper:

- Trimble GPS:

- 4-Measuring tape:

Tree features of the Atrush Forest:

Forest has an predestined 41 trees, the three generality usual species are Pinus brutia (Turkish pine) (45.0percent), Plantanus orientalis (Oriental plane tree) (17.5 percent), and Quercus aegilops (Ajo mountain scrub oak), (15.0percent).

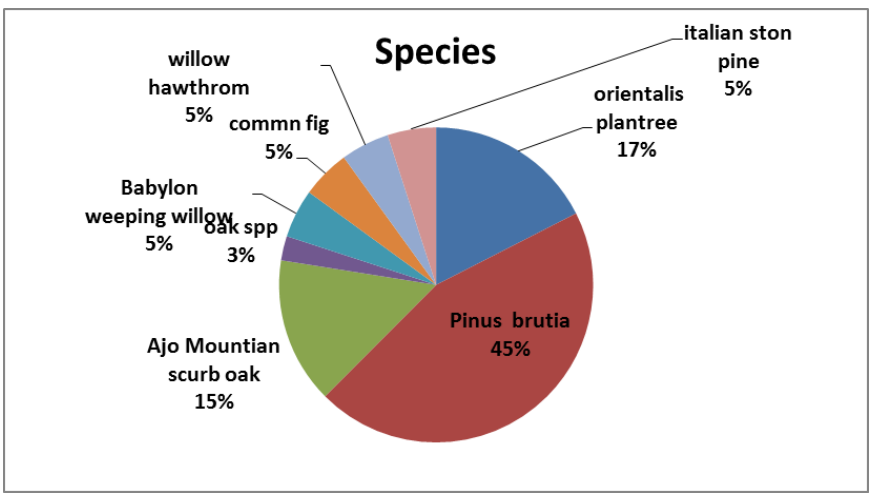

Figure 2. Tree species composition in |Atrush forest Source: By the researches depending on analysis of I-Tree Eco. Application 


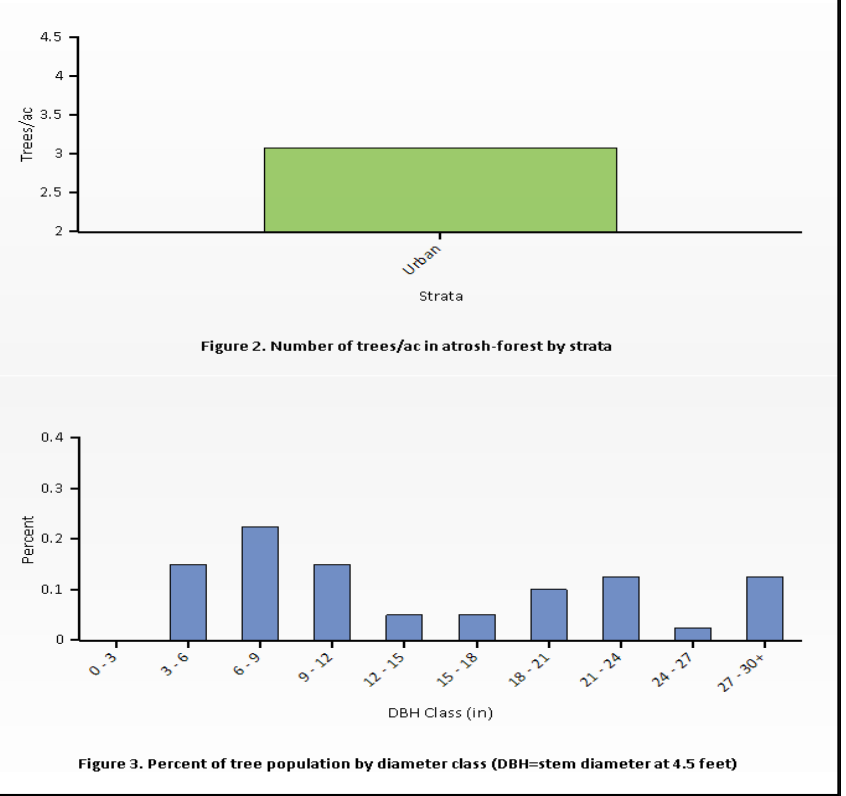

Figure 3.The Overall Tree Intensity in Atrush Forest (trees/acre)

Source: By the researches depending on analysis of I-Tree Eco. Application

\subsection{Air Pollution Departure by Trees}

Needy air standard is a regular trouble in numerous urban areas. It can command to reduce human health, harm to lands mantle substance and ecosystem procedure. The urban forest can aid to make better air standard by decreasing air temperature, straight detach pollution from the air, and decreasing energy exhaustion in buildings, which as a result reduces air pollutant discharge from the power sources. Trees also release evaporative organic groups that can share ozone; studies have showed that an increase in tree coating leads to lower ozone formation. (Nowak, D. 2002).

Pollution removal by trees and shrubs in Atrush-forest was evaluated using field data and latest advisable pollution and weather data. Pollution removal was greatest for ozone (Figure 4). It is estimated that trees and shrubs remove 0.106 tons of air pollution (ozone $\left(\mathrm{O}^{3}\right)$, carbon monoxide $(\mathrm{CO})$, nitrogen dioxide $\left(\mathrm{NO}_{2}\right)$, particular matter less than 2.5 microns $\left(\mathrm{PM}_{2.5}\right)$, and sulfur dioxide $\left(\mathrm{SO}_{2}\right)$ ) per year with a connected value of $\$ 280$.

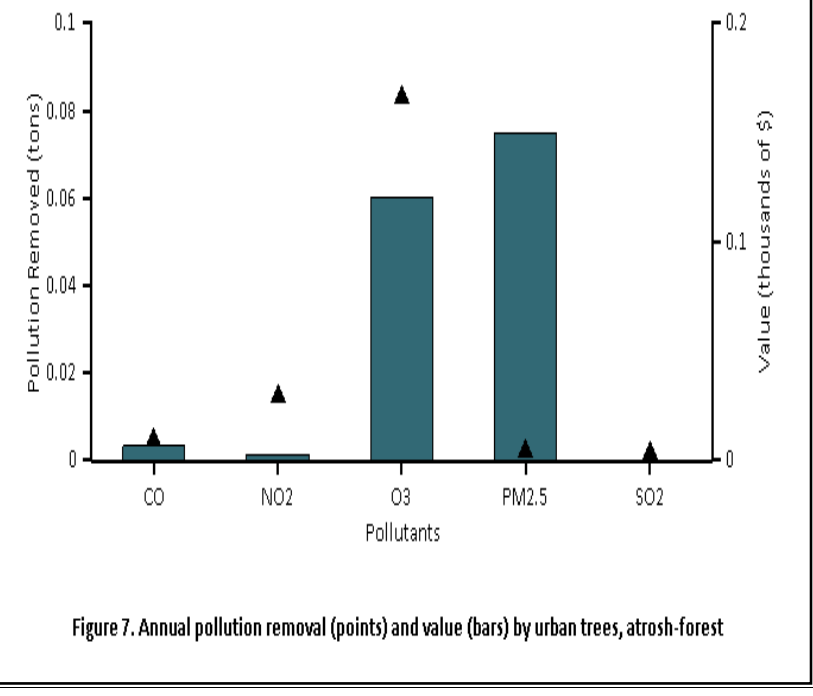

Figure 4.Annual Pollution Removal ( points) and Value (bars) by urban Trees (Atrush Forest)

Source: By the researches depending on analysis of I-Tree Eco. Application

\subsection{Oxygen Production}

Oxygen production is one of the ultimate usually quote benefits of urban trees. The net annual oxygen production of a tree is directly connected to the quantity of carbon sequestered by the tree, which is link to the collection of tree biomass. Trees in Atrush produce (2) tons of oxygen per year. ( David J. et.al 2006). However, this tree benefit is comparatively unimportant because of the large and comparatively amount of oxygen in the atmosphere and wide production by hydrous systems; atmosphere has a vast stock of oxygen. If all fossil fire stocks all trees, and all organic affairs in soils were fired, atmospheric oxygen would only drop a few percent.( Murray, F. et. al 1994).

Table (1): The oxygen production species

\begin{tabular}{|l|c|c|}
\hline \multirow{2}{*}{ Species } & Number & \\
& of & Oxygen(ton) \\
& Trees & \\
\hline
\end{tabular}




\begin{tabular}{|l|l|l|}
\hline $\begin{array}{l}\text { Plantanus orientalis(Oriental plane } \\
\text { tree) }\end{array}$ & 7 & 0.79 \\
\hline Pinus brutia(Turkish pine) & 19 & 0.34 \\
\hline $\begin{array}{l}\text { Quercus aegilops (Ajo mountain } \\
\text { scrub oak) }\end{array}$ & 6 & 0.23 \\
\hline Quercus infectoria(oak spp) & 1 & 0.08 \\
\hline $\begin{array}{l}\text { Salix babylonica(Babylon weeping } \\
\text { willow) }\end{array}$ & 2 & 0.06 \\
\hline Ficus carica(Common fig) & 2 & 0.05 \\
\hline Crataegus saligna(Peking Willow) & 2 & 0.04 \\
\hline Pinus pinea(Itailian stone pine) & 2 & 0.02 \\
\hline
\end{tabular}

Source: Survey Filed Forms

Table (1) shows the variety numbers of trees, where the type of dominant is Pinus brutia (Turkish pine). It has around (19) trees, as the type seems to be Quercus infectoria (oak spp), less existent in the study area, closest numbers for each of Salix babylonica (Babylon weeping willow), Ficus carica (Commonfig), Crataegus saligna (Peking Willow), Pinus pinea (Itailian stone pine). The types that has been detected and field measurement produces different quantity of oxygen as it is related to size, healthy leaf surface area of the tree, ground cover ,land use, tree height and crown width, also shows the Plantanus orientalis (Oriental plane tree) produce more oxygen around (0.79) ton. This indicates that the mentioned type is largest size for the wide leaf area. While the Pinus pinea (Itailian stone pine) species produce less oxygen around (0.02) ton. Whereas the number of trees been defected and measured in the study area is around (2) trees respectively. This is due to the small size of leaf area comparing it to another species in Atrush forest. While these species produce $(0.06,0.05,0.04,0.02)$ ton or closest amount of oxygen.

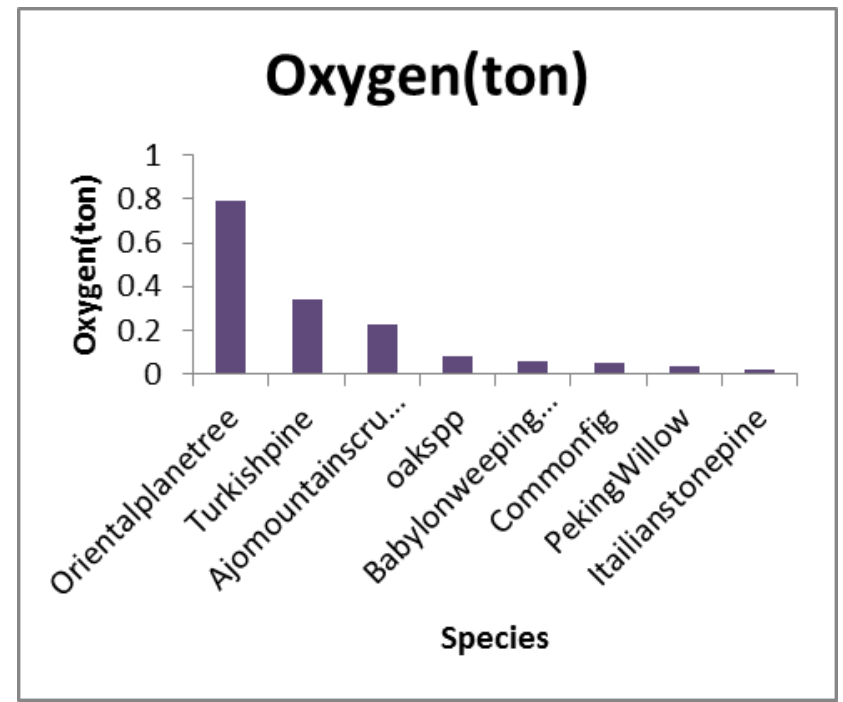

Figure 5. Oxygen production of trees by Strata

Source: survey filed forms

\section{Results and Discussions}

To analyze the environmental and economic benefits of the selected urban forest areas (Atrush), a complete inventory of the sample trees were processed using software-Eco program of I-Tree.

An I-Tree Eco is generated to employ united field data from at random situated lands and local hourly air pollution and meteorological data to determine urban forest construction and its many. ( Nowak D.,et. al .2007).

Including amount of pollution isolated hourly by the urban forest, and its related percent air purity advanced during a year. Exemplary, all field data are collected during the leaf-on season to really evaluate tree canopies. (Nowak, D., et. al 2008).

\subsection{Air Pollution Removal}

Pollution removal is calculated for ozone, sulfur dioxide, nitrogen dioxide, carbon monoxide and particulate matter less than 2.5 microns. Particulate matter less than10 microns (PM10) is another notable air pollutant. Given that I-Tree Eco analyzes particulate matter less than 2.5 microns $\left(\mathrm{PM}_{2.5}\right)$ which is a subdivision of PM10. PM10 has not been incorporate in this analysis. $\mathrm{PM}_{2.5}$ is mostly more 
pertinent in discussions concerning air pollution impacts on human health.

Air pollution removal estimates are obtained from calculated hourly tree-canopy impedance for ozone, sulfur and nitrogen dioxides based on a crossbred of big-leaf and multi-layer canopy sedimentation models. ( Baldocchi D. et.al 1987). As the removal of carbon monoxide and particulate matter by vegetation is not directly related to transpiration, removal rates (deposition velocities) for these pollutants were based on average measured values from the literature ( Baldocchi D. et.al 1987). that were modify rely on leaf phonology and leaf area. Particulate removal absorb 50 percent re suspension average of particles back to the atmosphere. (Zinke, P. 1967). Current updates (2011) to air quality modeling are established on recovered leaf area index regain, weather and contaminant processing and intercalation, and modernized pollutant monetary values. ( Hirabayashi, S. 2012).

Trees remove $\mathrm{PM}_{2.5}$ when particulate matter is charged on leaf surfaces [14] this charged $\mathrm{PM}_{2.5}$, can be estimated to the atmosphere or removed during rain proceedings and solution or move to the soil. This amalgamation of events can lead to positive or negative pollution removal and value depending on different atmospheric factors. Normally, $\mathrm{PM}_{2.5}$ removal is positive with positive benefits. However, there are some cases when net removal is negative or repenting particles lead to increased pollution focus and negative values. During some months (e.g. with no rain), trees repent more particles than they remove .Repenting can also lead to increase overall $\mathrm{PM}_{2.5}$ focus if the border category state are lower during net estimation time than during net removal time. Since, the pollution removal value is based on the change in pollution focus, it is potential to have situations when trees remove $\mathrm{PM}_{2.5}$ but increase concentrations and thus have negative values during period so positive over all removal. These events are not common, but can happen. For reports in the United States, default air pollution removal value is calculated based on local incidence of adverse health effects and national median externality costs. The number of adverse health effects and associated economic value is calculated for ozone, sulfur dioxide, nitrogen dioxide, and particulate matter less than 2.5 microns using data from the U.S. Environmental Protection Agency's Environmental Benefits Mapping and Analysis Program (Ben MAP) (Nowak D. et. al 2014) The model uses disadvantage purpose method that is based on the local change in pollution focus and inhabitants. National median externality costs were used to calculate the value of carbon monoxide removal (Murray, F. et. al 1994). For international reports that do not have local values, estimates are based on either European median externality values (Van Essen, H. et. al 2011). or Ben MA Progression equations (Nowak et al., 2014) that integrate userdefined inhabitants assessment. Values are then transformed to local money with user-defined commutation averages. For this analysis, pollution removal value is calculated based on the prices of $\$ 1,450$ ton (carbon monoxide), $\$ 1,445$ per ton (ozone), $\$ 184$ per ton (nitrogen dioxide), \$58 per ton (sulfur dioxide), $\$ 72,754$ per ton (particulate matter less than 2.5 microns).

Table (2): Benefit summery by species in Artosh forest :

\begin{tabular}{|l|c|l|l|}
\hline \multirow{2}{*}{ Species } & Trees & \multicolumn{2}{|l|}{ Pollution Removal } \\
\cline { 2 - 4 } & Number & Ton/Year & \$/year \\
\hline $\begin{array}{l}\text { Ficus carica (Common } \\
\text { fig) }\end{array}$ & 2 & 0.0009 & 1.47 \\
\hline $\begin{array}{l}\text { Pinus brutia (Turkish } \\
\text { pine) }\end{array}$ & 19 & 0.0081 & 13.44 \\
\hline Pinus pinea (Itailian & 2 & 0.0010 & 1.66 \\
\hline
\end{tabular}




\begin{tabular}{|l|c|l|l|}
\hline stone pine) & & & \\
\hline $\begin{array}{l}\text { Plantanus orientalis } \\
\text { (Oriental plane tree) }\end{array}$ & 7 & 0.0039 & 6.46 \\
\hline $\begin{array}{l}\text { Quercus infectoria (oak } \\
\text { spp) }\end{array}$ & 1 & 0.0001 & 0.24 \\
\hline $\begin{array}{l}\text { Quercus aegilops (Ajo } \\
\text { mountain scrub oak) }\end{array}$ & 6 & 0.0006 & 0.99 \\
\hline $\begin{array}{l}\text { Salix babylonica } \\
\text { (Babylon weeping } \\
\text { willow) saligna }\end{array}$ & 2 & 0.0003 & 0.48 \\
\hline $\begin{array}{l}\text { Crataegus } \\
\text { (Peking Willow) }\end{array}$ & 41 & 0.0157 & 26.07 \\
\hline Total
\end{tabular}

Source: By the researches depending on analysis of I-Tree Eco. Application

Table (2) estimated the economic cost to remove the pollution in the air via (carbon monoxide, ozone, nitrogen dioxide, sulfur dioxide, particulate matter less than 2.5microns).

The above table (2) shows economic values calculated by US Dollars differently. The more increase number of trees, the highest financial cost to remove the pollution. Note that Pinus brutia (Turkish pine), which formed the highest number of study area (19) trees, gained economical profiles (13.44\$/year) with proportion of (0.01 ton/year) of pollution. The total economic cost for trees species detected in Atrush forest to remove pollution (0.01576 ton/year) is around (26.07 \$) annually.

\subsection{Oxygen Production}

The amount of oxygen produced is estimated from carbon sequestration based on atomic weights:

net $\mathrm{O}_{2}$ release $(\mathrm{kg} /$ year $)=$ net $\mathrm{C}$ sequestration $(\mathrm{kg} /$ year $)$ $\times 32 / 12$.

To estimate the net carbon sequestration rate, the amount of carbon sequestered as a result of tree growth is reduced by the amount lost resulting from tree death. So, net carbon sequestration and net annual oxygen production of the urban forest account for dissolution (Nowak et al., 2007). For complete inventory projects, oxygen production is estimated from total carbon sequestration and does not account for dissolution.

Table (3): Oxygen Production of Trees by Strata in Atrush forest

\begin{tabular}{|l|l|l|}
\hline Strata & $\begin{array}{l}\text { Oxygen Production } \\
\text { (ton) }\end{array}$ & $\begin{array}{l}\text { Oxygen Production } \\
\text { Density } \\
\text { (kg/year/ha) }\end{array}$ \\
\hline $\begin{array}{l}\text { Atrush } \\
\text { forest }\end{array}$ & 1.50 & 269.60 \\
\hline
\end{tabular}

Source: By the researcher depending on analysis of I-Tree Eco. Application

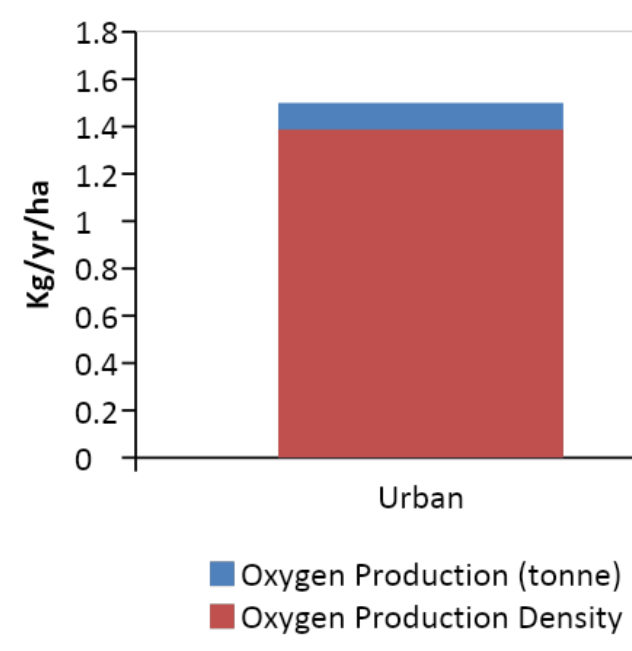

Figure 6.Oxygen Production of Trees by Strata in Atrush Forest

Source: Survey Filed Forms

The environmental value and economic cost which produces different trees. While, comparing them with various it shows similarity between the current study and with the study of (David J. et. al 2006). They indicates to the function of urban vegetation in the shape and decomposition of air pollutants in cities, which agree with the allude to subject in his study (Air pollution removal by urban trees and shrubs in the United States). Also, the researcher (Ninan, K. 2014). indicates in his study ( Valuing Forest Ecosystem Services and Disservices- Case Study of a Protected Area in India), that forests have been valued only for the tangible benefits they bring such as timber and nontimber forest yield. The intangible benefits provided by 
forests such as watershed and soil protection, regulating climate, nutrient cycling, have been command ago, these are not business in festival markets or challenging to value. If these values could be poisoned and in decision making it could lead to excel preservation effect, particularly in toughen the economic case for excuse preservation of forests against amusing them to non-forest uses, in India which have reliable to impose the economic value of the services provided by its forests.

\section{Conclusions and Recommendations}

\subsection{Conclusions}

From the results of this study we can put the following conclusions:

- Assessing indirect benefits provided by forests has been very difficult, but using modern methods of evaluation, especially the adoption of an I- tree program, the process become possible and yields good results.

- The results of the evaluation proved that forests play an important role in environmental aspects and give positive returns that can be converted into monetary units.

- Trees species Differ in their contributions to the environmental aspects, this makes biodiversity important for the preservation of the environment.

- Pollution removal by trees and shrubs in Atrushforest was evaluated using field data and latest advisable pollution and weather data. Pollution removal was greatest for ozone (Figure 4). It is estimated that trees and shrubs remove 0.106 tons of air pollution (ozone $\left(\mathrm{O}^{3}\right)$, carbon monoxide $(\mathrm{CO})$, nitrogen dioxide $\left(\mathrm{NO}_{2}\right)$, particular matter less than 2.5 microns $\left(\mathrm{PM}_{2.5}\right)$, and sulfur dioxide $\left.\left(\mathrm{SO}_{2}\right)\right)$ per year with a connected value of \$280. This mater reflect the important role of trees and forest in affecting on air pollution in reducing these gases from the atmosphere, and there are no other things can present this role.

\subsection{Recommendations}

Based on the findings and conclusions, the following recommendations were made:

- Pay attention to plant forest as they are significant element in oxygen production and removable of variety pollution .Furthermore, it is an economical factor that gains strategic and financial profits.

- Conducting silviculture operation and maintenance the green biomass which is existed in urban and rural regions in order to obtain general and special economic and environmental profits.

- Pay attention to planting forest with species wide leaf area since they have more capability and ability to introduce environmental factors such as oxygen production or contribution for pollution removable which is existed in the air.

- Increasing the green biomass areas inside the urban cities in particular, due to the high percentage of pollution in the urban environment especially Iraqi Kurdistan Region cities and towns.

- Increasing tree cover of Iraqi Kurdistan Region leads to reduce ozone formation.

- We propose to allocate a percentage of public revenues provided by non-renewable resources to be spent on renewable resources such as forests.

\section{References}

1. Baldocchi D. D. Hicks, .B. Camara, 1987 .A canopy stomat alresistance model for gaseous deposition to vegetated surfaces.AtmosphericEnvironment.21:91-101.

2. Bidwell, R. .S. Fraser, (1972). Carbon monoxide uptake and metabolism by leaves. Canadian Journal of Botany.50:1435-1439.

3. Broecker, W.(1970). Man's oxygen reserve. Science168 (3939):1537-1538.

4. David J. Nowak , Daniel E. Crane, Jack C. Stevens USDA 
Forest Service, Northeastern Research Station, 5 Moon Library, SUNY-ESF, Syracuse, NY 13210 USA Urban Forestry \& Urban Greening 4 (2006) 115 - 123.

5. Hirabayashi, S. 2012. iTree Eco Precipitation Interception Model Descriptions, http://www. Itree tools. org/eco/ resources/ I Tree_Eco_ Precipitation_ Interception_ Model_Descriptions_V1_2.pdf.

6. Murray, F., Marsh L. , Bradford, P. 1994. New York State Energy Plan, vol. II: issue reports. Albany, NY: NewYork State Energy Office.

7. Naumoski A. (2016), “Estimating the Country Risk Premium in Emerging Markets: the Case of the Republic of Macedonia", Financial Theory and Practice, No. 36 (4), pp. 413-434.

8. Nowak, D. 1995. Trees pollute? A"TREE" explain sitall. In: Proceedings of the 7 thNational Urban Forestry Conference. Washington, DC: AmericanForests:28-30.

9. Nowak,D.J.2000. The interactions between urban forests and global climate change. In :Abdollahi, K.K. ;Ning ,Z.H.;Appeaning ,A.,eds .Global Climate Change and the Urban Forest . Baton Rouge,LA: GCRCCand Frankl in Press:31-44.

10. Nowak D, Hirabayashi,S,BodineA,Greenfield,E. 2014. Tree and forest effects on air quality and human health in the United States. Environmental Pollution.193:119-129.

11. Nowak D., Hirabayashi S., Bodine A. and Hoehn, R. 2013. Modeled PM2.5 removal by trees in Ten U.S. Cities and associated health effects. Environmental Pollution.178:395402.9999 .

12. Nowak, D., Crane, D.E.Dwyer,J.F.2002a. Compensatory value of urban trees in the United States .Journal of Arboriculture.28 (4):194-199.

13. NowakD.,Hoehn,R.,Crane,D.2007.Oxygen production by urban trees in the United States. Arboriculture \&Urban Forestry.33(3):220-226.

14. Nowak, D., Hoehn, R., Crane, D., Stevens ,J. , Walton, J., and bond, J. 2008. Aground-based method of assessing urban forest structure and ecosystem services. Arboriculture and Urban Forestry. 34(6):347-358.

15. Ninan, K. 2014. Valuing Ecosystem Services-
Methodological Issues and Case Studies. Edward Elgar Publishing. Cheltenham and Northampton.

16. Gretchen C. Daily, Panel Chair, Department of Biological Sciences, Stanford University, Stanford, CA 94305(1997).

17. Van Essen, H.; Schroten, A.; Otten, M.; Sutter, D.; Schreyer, C.; Zandonella, R.; Maibach, M.; Doll, C. 2011. External Costs of Transport in Europe. Netherlands: CE Delft. 161 p.

18. Zinke, P. 1967.Forest interception studies in the United States. In: Sopper, W.E. ;Lull,H.W.,eds. Forest Hydrology. Oxford, UK: Pergamon Press:137-161. 